\title{
A INFLUÊNCIA DE LUTERO NA PESQUISA BRASILEIRA EM EDUCAÇÃO: UMA NOVA PERSPECTIVA TEÓRICA
}

\author{
THE INFLUENCE OF LUTHER IN BRAZILIAN RESEARCH IN \\ EDUCATION: A NEW THEORETICAL PERSPECTIVE
}

\section{LA INFLUENCIA DE LUTERO EN LA INVESTIGACIÓN BRASILEÑA EN EDUCACIÓN: UNA NUEVA PERSPECTIVA TEÓRICA}

\author{
EVALdo Luis PaulY ${ }^{\mathrm{I}}$ \\ Anselmo ERnesto GrafF ${ }^{\mathrm{I}}$
}

\begin{abstract}
Resumo Este ensaio discute a influência de Lutero na educação a partir da dialética entre sua eclesiologia, antropologia e catequética. Apresenta a experiência da cidade de Leisnig e a polêmica de Lutero contra a noção antropológica do livre-arbítrio de Erasmo, demonstrando como essa antropologia "pessimista" se articula em uma didática "otimista" nos Catecismos Maior e Menor. A metodologia utiliza a pesquisa bibliográfica e análise documental de textos eclesiais, antropológicos e catequéticos. Os resultados apontam para três possíveis contribuições de Lutero para a pesquisa brasileira em Educação: 1) A escola que atende ao interesse eclesial da Reforma é a escola pública, universal e gratuita; 2) Lutero se contrapõe aos pedagogos humanistas de seu tempo e sua visão otimista do ser humano, afirmando a tese de que a pessoa é boa e má ao mesmo tempo e que essa tensão só se resolve através da justificação pela fé; 3) O objetivo pedagógico dos Catecismos é atender aos anseios das pessoas em suas vidas cotidianas e laborais, a partir de uma pedagogia sensível e teleológica. A conclusão revela em dois casos exemplares como a metodologia teológica de Lutero pode contribuir em temas polêmicos sobre os quais a pesquisa em Educação ainda não possui consensos sólidos, como são a formação para a cidadania e a crítica à influência da globalização no campo da política educacional.

Palavras-chave: Lutero, Martinho; Antropologia Educacional; Globalização e EduCAÇÃo; EducaÇão Para A CidAdania; Religião E EduCAÇão.
\end{abstract}

${ }^{\mathrm{I}}$ Universidade La Salle (UNILASALLE), Canoas/RS - Brasil. 
Abstract This essay discusses Luther's influence on education from the dialectic point of view of his ecclesiology, anthropology and catechetics. It presents the experience of the city of Leisnig and the polemic of Luther against the anthropological notion of Erasmus' free will, demonstrating how this "pessimistic" anthropology articulates itself in an "optimistic" didactic in the Major and Minor Catechisms. The methodology uses the bibliographical research and documentary analysis of ecclesial, anthropological and catechetical texts. The results point to three possible contributions of Luther to the Brazilian research in Education: 1) The school that serves the Reformation's ecclesial interest is the public, universal and free school; 2) Luther contrasts with the humanist pedagogues of his time and his optimistic vision of the human being, affirming the thesis that the person is good and bad at the same time and that this tension is only resolved through the justification by faith; 3) The pedagogical objective of the Catechisms is to attend to the needs of the people in their daily lives and work, from a sensitive and teleological pedagogy. The conclusion shows in two exemplary cases how Luther's theological methodology can contribute to controversial issues on which research in Education still does not have solid consensuses, such as formation for citizenship and criticism of the influence of globalization in the field of educational policy.

Keywords: Luther, Martin; Educational Anthropology; Globalization and Education; EDUCATION FOR CITIZENSHIP; RELIGION AND EDUCATION.

Resumen En este ensayo se analiza la influencia de Lutero en la enseñanza de la dialéctica entre su eclesiología, la antropología y la catequesis. Se presenta la experiencia de la ciudad de Leisnig y la controversia de Lutero contra la noción antropológica de la libre voluntad de Erasmo, demostrando cómo esta antropología "pesimista" se divide en una didáctica "optimista" en los Catecismos Mayor y Menor. La metodología utiliza la búsqueda bibliográfica y análisis de documentos eclesiales, antropológicos y los textos catequéticos. Los resultados apuntan a tres posibles contribuciones de Lutero para la educación brasileña de investigación: 1) La escuela que sirve a los fines eclesiales de la Reforma es la escuela pública, universal y gratuita; 2) Lutero se opone a los educadores humanistas de su tiempo con su visión optimista del ser humano, sosteniendo la tesis de que la persona que es buena y mala al mismo tiempo y que esta tensión se resuelve sólo a través de la justificación por la fe; 3) El objetivo pedagógico de la catequesis es satisfacer los anhelos de las personas en su vida cotidiana y de trabajo, a partir de una pedagogía sensible y teleológica. La conclusión muestra en los casos duplicados como la metodología teológica de Lutero puede contribuir en temas controvertidos en los que la investigación en la educación no tiene un consenso sólido, como son la formación de la ciudadanía y crítica a la influencia de la globalización en el ámbito de la política educativa.

Palabras clave: Lutero, Martín; Antropología de la educación; La globalización y la EDUCACIÓN; EDUCACIÓN PARA LA CIUDADANÍA; La RELIGIÓN Y LA EDUCACIÓN. 


\section{INTRODUÇÃO}

A teologia de Lutero não produziu novidades para justificar a educação de crianças porque, desde os seus primórdios, a tradição judaico-cristã prioriza a educação. Essa tradição está presente na figura patriarcal de Moisés que enfrenta o Faraó Ramsés II da $19^{\mathrm{a}}$ Dinastia (1304-1181 a.C.). Ramsés II, provavelmente, temendo uma coligação política das tribos seminômades provenientes do deserto com os clãs camponeses sedentários descendentes de Jacó, decretou o recrudescimento da corveia. Diferente do trabalho escravo, a corveia consistia no recrutamento obrigatório dos camponeses durante a entressafra, para trabalho forçado temporário na construção ou conservação de obras públicas para o Faraó, geralmente, nos canais de irrigação. A imagem dos hebreus construindo as pirâmides do Egito é uma criação hollywoodiana e não reproduz a realidade histórica do século 12 a.C., época histórica do surgimento do povo de Deus. Nesse século, as pirâmides já estavam edificadas havia mais de mil anos. O primeiro capítulo do livro de Êxodo descreve uma corveia. A tribo de Jacó, exilada em Gosém, constrói silos para cereais. A opressão recrudesce quando o governo faraônico exige que as parteiras judias afoguem os meninos (Êx 1.22). Nessa ocasião, as parteiras e mães decidem praticar a desobediência civil para salvar os meninos, entre os quais Moisés. Para a Bíblia, a insurreição dessas mulheres em defesa das crianças (Êx 1.15-21; CARDOSO, 1984, p. 34) desencadeia a libertação do Egito de um grupo de "h'apirus"1 em 1250 a.C. Esse é o fato histórico que molda a identidade do povo de Deus.

No fluxo dessa luta popular, Deus promete salvar o seu povo, dando-lhe terra e filhos. Até hoje o povo considera que crianças para criar e terra para plantar são bênção divina. Um dos títulos bíblicos para designar a Deus é "Javé, que faz justiça a órfãos e viúvas". Essa preferência de Deus por crianças e mulheres desamparadas caracteriza a religião do povo judeu e dos povos cristãos. Séculos depois, na diáspora de Israel, o Rabino Hudah Nesiah, em torno de 210 d.C., escrevia que o mundo "se sustenta apenas sobre o murmúrio das crianças na escola [...]. Não deixem pois que as crianças sejam mantidas afastadas da escola, mesmo que seja para a construção do Templo" (apud WEBER, 1986, p. 42). A educação de crianças nas escolas é assumida como um valor ético, político, cultural e religioso superior à reconstrução do Templo e restauração do culto sacerdotal. A reconstrução do Templo de Jerusalém, destruído pelas legiões de Tito em 70 d.C., significava a própria reorganização do Estado de Israel como nação independente! Nem mesmo a independência nacional vale mais que a educação escolar de crianças saudáveis e barulhentas. A teologia cristã e Lutero herdam essa radical valorização religiosa da educação de crianças.

Algumas pesquisas brasileiras recentes na área da educação costumam analisar a contribuição de Lutero para a pedagogia, a partir de algumas de suas obras produzidas no con-

H'apiru é um termo egípcio que designa o trabalhador da corveia que se transformará, por semitização, em hebreu. "Sabemos da existência de muitos apiru entre os seus (de Ramsés II) escravos empregados como lavradores, a sua revolta e fuga constituem o verdadeiro começo da história dos judeus" (MCEVEDY, 1990, p. 36). 
texto da conjuntura política (AHLERT, 2006, 2007; BARBOSA, 2007, 2011; JARDILINO, 2009; KEIM, 2010; PAULY, 2002, 2011). Em geral, essa pesquisa sobre Lutero recorre aos seguintes textos: À nobreza cristã da nação alemã, acerca da melhoria do estamento cristão (1520); Da autoridade secular, até que ponto se lhe deve obediência (1523); Aos conselhos de todas as cidades da Alemanha, para que criem e mantenham escolas (1524); Tratado de Martinho Lutero sobre a liberdade cristã (1520); Uma prédica para que se mandem os filhos à escola (1530). ${ }^{2}$ Essas obras relacionam-se com a educação e se fundamentam principalmente nas concepções políticas do reformador. Essas obras, no entanto, podem ser classificadas como periféricas em relação ao centro da teologia luterana e, portanto, de sua produção intelectual mais relevante. Assim, nos parece necessário e possível relacionar alguns temas estratégicos ou centrais de sua teologia com a pedagogia, como a concepção de igreja, de ser humano e de catequese.

Uma mudança no enfoque pedagógico tradicional sobre Lutero talvez seja interessante porque os textos políticos de Lutero nos parecem menos instigadores para a pedagogia do que as concepções luteranas de eclesiologia, antropologia e catequética, temas centrais na teologia da Reforma. A hipótese do artigo é que Lutero, como pensador político, está imerso na cultura e no paradigma social da cristandade, portanto, não poderia conceber um Estado democrático e laico porque não rompeu completamente com a concepção político-religiosa da cristandade europeia. Essa hipótese considera que, em termos políticos modernos, Lutero foi democrático na gestão paroquial (poder municipal), aristocrático no principado (poder provincial) e teocrático no Reino (poder nacional). Lutero vivenciou e sofreu a dramática e complexa conjuntura política sob a qual reinava Carlos V, Imperador do Sacro Império Romano Germânico. Em função dessa hipótese, analisaremos a relação de Lutero com a educação desde três novas perspectivas teóricas. Uma primeira abordagem será a sua eclesiologia esboçada nas obras: Direito e autoridade de uma assembleia ou comunidade cristã de julgar toda doutrina, chamar, nomear e demitir pregadores - Fundamento e razão da Escritura (1523), o Estatuto para uma caixa comunitária. Orientação sobre como lidar com o patrimônio eclesiástico (1523). Uma segunda perspectiva teórica relaciona a concepção antropológica luterana forjada na polêmica obra Da vontade cativa (1525), na qual Lutero se contrapõe a Erasmo, seu contemporâneo e pedagogo humanista, bem conhecido pela educação moderna; finalmente, a partir de sua perspectiva catequética, analisaremos os pressupostos didáticos que se podem perceber nos clássicos Catecismos Menor e Maior.

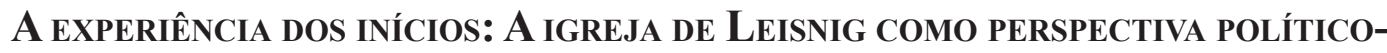 -PEDAGógica da EClesiologia Luterana}

Conforme Ricardo Rieth, na "Introdução" ao Estatuto para uma Caixa Comunitária (2000, p. 37-44), a organização paroquial de Leisnig "logo foi assumida por outras cidades,

2 A edição das Obras Selecionadas de Martinho Lutero, publicada pelas editoras Sinodal e Concórdia vinculadas às duas maiores igrejas luteranas brasileiras, possui 12 volumes. O índice está disponível em: http:// www3.est.edu.br/biblioteca/indice lutero.htm 
como Magdeburgo, Stralsund, Königsberg, Breslau e Plauen”. A brevidade e a derrota política dessa experiência popular destacam a sua relevância teórica para a reflexão pedagógica a partir da eclesiologia luterana.

Poucas semanas após a visita de Lutero, realizada em 25 de setembro de 1522, a "comunidade de Leisnig, pequena aldeia da Saxônia sobre o rio Mulde" realizou uma assembleia geral, durante a qual "destituiu o sacerdote titular e chamou a dois ministros evangélicos". Essa mudança religiosa gerou uma gama de novos problemas, fazendo que o povo luterano de Leisnig enfrentasse a "necessidade de administrar os recursos financeiros da comunidade que, até então, haviam estado sob a supervisão do abade do monastério" (BAHMANN, 1977, p. 91), essa era uma situação típica do regime da cristandade. A comunidade de Leisnig, em 1523, escreveu a Lutero pedindo o seu parecer sobre o "Estatuto para uma Caixa Comunitária. Orientação sobre como lidar com patrimônio eclesiástico" (LUTERO, 2000, p. 37-64). A resposta de Lutero para a comunidade tornou-se pública por iniciativa do reformador, que considerou:

\footnotetext{
...bom que mencionado estatuto fosse publicado, na esperança de que Deus the irá conceder sua bênção graciosa, a fim de que se torne um exemplo geral a ser seguido por muitas outras comunidades, $[\ldots]$ tendes que consolar-vos com o fato e considerar que, se aquilo que empreendeis for de Deus, necessariamente encontrará forte resistência, pois o impertinente satanás não dará descanso nem tira folga (LUTERO, 2000, p. 45).
}

O Acordo inicia definindo que o "provisionamento de nosso pastorado comum, incluindo chamado, eleição, admissão e destituição de nossos pastores" (LUTERO, 2000, p. 50) é responsabilidade da "assembleia paroquial". A seguir, a ata do "acordo fraternal" estabelecido pelos homens e mulheres de Leisnig, passa a definir o destino dos diversos ingressos financeiros da comunidade. A gestão da "caixa comunitária" será realizada por "dez provedores ou administradores" eleitos anualmente, no segundo domingo após a epifania, em assembleia geral da paróquia, com início às 11 horas (LUTERO, 2000, p. 54). O Estatuto previa que o cofre da comunidade fosse fechado e aberto através de quatro cadeados com "quatro chaves diferentes, ficando uma com os nobres, uma com o conselho [da cidade], uma com os cidadãos comuns da cidade e outra, com os camponeses da área rural" (LUTERO, 2000, p. 55). Os administradores reuniam-se semanalmente para controlar os ingressos e verificar as cobranças. Os administradores também nomeavam zeladores para a conservação dos edifícios "da igreja, das pontes, da casa paroquial, das escolas, das sacristias e dos hospitais" (LUTERO, 2000, p. 56). O Acordo proibiu a mendicância na cidade, fosse ela praticada por pobres, estudantes ou ordens mendicantes. Os mendigos deveriam ser expulsos da cidade, todavia, moradores empobrecidos por doença, velhice, orfandade ou outra adversidade deveriam ser mantidos com recursos da caixa comum. Leisnig inventou uma forma de seguridade social visando à redução ou mesmo extinção da pobreza. A caixa comum também funcionava como banco de fomento, realizando empréstimos para: 


\begin{abstract}
...artesãos ou outras pessoas pobres residentes, casados ou viúvos que moram na cidade e nas aldeias de nossa paróquia e que não têm recursos próprios, nem podem contar com ajuda alheia para exercerem devidamente sua profissão e trabalhar, seja como artesãos na cidade, ou como agricultores, a esses os administradores concederão, de recursos da caixa comunitária, adiantamentos adequados a serem devolvidos em determinado prazo. Aqueles, porém, que, apesar de trabalho dedicado, não têm condições de devolver o empréstimo, terão a dívida perdoada por amor de Deus, para as suas necessidades. Esses casos devem ser examinados cuidadosamente pelos administradores (LUTERO, 2000, p. 61).
\end{abstract}

Esse fomento à emancipação dos pobres pelo trabalho é estendido também aos "estranhos imigrados". Outra atividade de fomento decorreu da decisão de que a caixa comunitária deveria comprar uma reserva de cereais para formar um "estoque comunitário", adquirido durante a safra para que, nos tempos de escassez, os habitantes de Leisnig pudessem adquirir cereais dessa reserva por compra, empréstimo ou doação (LINDBERG, 2001, p. 145-149), prevenindo a carestia de alimentos e a consequente fome tão comum nas cidades europeias do século XVI.

Por óbvio, a comunhão espiritual, econômica, assistencial e política da comunidade luterana de Leisnig produziu uma autonomia da cidade em relação aos interesses dos príncipes e senhores territoriais. Essa organização eclesial extemporânea e radicalmente democrática manteve-se pelo breve período de 1522 a 1525. Com a vitória dos proprietários de terras na Guerra dos Camponeses, os príncipes eleitores alemães agiram contra essa organização comunitária de Leisnig e impuseram uma legislação centralizadora da vida social pelo Estado, impedindo a continuidade desse governo local ancorado na democracia direta, implantada em Leisnig quando da adesão do seu povo ao luteranismo. O Acordo Fraternal foi implementado por apenas quatro anos, razão pela qual a historiografia eclesiástica luterana não lhe dedica maiores estudos. Essa experiência, mesmo que derrotada, parece paradigmática para pensar a educação a partir da contribuição teológica luterana:

A cidadezinha de Leisnig tornou-se a primeira comunidade luterana organizada. Seu estatuto foi preservado. Ele dedica um capítulo inteiro à sua escola pública não-estatal! Isto em 1523! A escola da igreja de Leisnig atendia 45 alunos em 1529, numa população de 3 mil habitantes. A escola contava com um professor para os meninos e uma "senhora honesta, já de certa idade e irrepreensível", para as meninas menores de 12 anos. Eram eleitos e avaliados pela assembleia paroquial anual, que também definia seus salários (PAULY, 2002, p. 155).

Após essa breve e fracassada experiência democrática, as comunidades luteranas, ao se tornarem independentes da jurisdição católica, passaram a se submeter ao governo dos príncipes territoriais. Essa submissão tornou-se inevitável na tensa conjuntura política do início da Reforma, demarcada pelas tensões externas em relação ao Império e internas em relação à Guerra dos Camponeses. 


\section{A ANTROPOlOGIA DE LUTERo EM PERSPECTIVA ANTROPOLÓGICO-PEDAGÓGICA}

Parece plausível supor que diante da derrota jurídica e política sofrida pela comunidade de Leisnig, Lutero tenha passado a dedicar-se à defesa da liberdade pessoal de cada cristão como indivíduo. A liberdade individual foi o espaço político no qual a teologia de Lutero pôde avançar naquele contexto. Como não foi possível experimentar uma nova sociedade a partir da eclesiologia reformada, tornou-se mais viável construir uma nova concepção de pessoa a partir da antropologia cristã. É o que despontará no livro antropológico mais elaborado de Lutero: Da vontade Cativa. Nessa obra, Lutero confronta a sua concepção antropológica do servo-arbítrio contra o livre-arbítrio do humanista Erasmo. Lutero entende que as pessoas são boas e más ao mesmo tempo e sob as mesmas circunstâncias. Essa concepção antropológica parece relevante para a educação:

\footnotetext{
Pergunta à experiência o quanto é impossível persuadir pessoas que se apegaram a alguma coisa com afeto. $\mathrm{Ou}$, se cedem, cedem à força ou à maior vantagem de outra coisa. Jamais cedem espontaneamente. Se, porém, não possuem tal afeto, deixam que as coisas andem e se façam como quiserem.

[...] Dessa maneira a vontade humana está colocada no meio, como um jumento. Se Deus está sentado nele, ele quer e vai como Deus quer, [...]. Se Satanás está sentado nele, ele quer e vai como quer Satanás, e não está em seu arbítrio correr para um dos cavaleiros ou procurá-los, antes, os próprios cavaleiros lutam para o obter e possuir (LUTERO, 1993, p. 49).
}

Lutero sabe que a sua afirmação implica em contradição filosófica que, no entanto, torna-se verdadeira pela revelação bíblica de que Deus, e apenas Deus, possui, de fato, a qualidade do livre-arbítrio. O desejo ou a vontade determinada, portanto, caracterizam o ser humano. Uma concepção semelhante acerca do desejo humano só encontrará paralelo na psicanálise, séculos mais tarde. Não cabe em Lutero qualquer filosofia da vontade. Sua antropologia dualista, determinada apenas pelo combate escatológico entre Deus e Satanás, nos parece - pedagogos do século XXI - um absurdo antropológico medieval. Cabe perguntar, no entanto, o que resta às pessoas que compreendem que, de fato, não está nelas o poder de determinar sua própria salvação? Livres de determinarem a sua própria salvação, as pessoas estão livres para compreender racionalmente quais são, de fato, as determinações objetivas e materiais para o exercício de seu poder como seres humanos que agem em e sob condições concretas da realidade imediata. Na formulação luterana:

\footnotetext{
...se queremos viver piedosamente, é necessário que mantenhamos uma distinção certíssima entre a força de Deus e a nossa, entre a obra de Deus e a nossa. Vês, assim, que esse problema é uma das partes de toda a suma das coisas cristãs; dele depende e nele está em jogo o conhecimento de si mesmo, assim como o conhecimento e a glória de Deus (LUTERO, 1993, p. 29).
}

A vida piedosa é capaz de distinguir entre o poder humano e o poder divino, ou seja, a piedade consiste, por um lado, no exercício da racionalidade para pensar sobre a realidade 
do mundo, das ciências, da vida real, da política; por outro, no exercício espiritual de contemplar o poder transcendental de Deus, da obra divina da salvação que, conforme a revelação bíblica depende exclusivamente da cruz de Cristo e da justificação somente pela fé. Essa capacidade cognitiva de distinguir entre os poderes humanos e os divinos demarca os primórdios de uma das características da educação republicana cuja finalidade é propiciar a todas as pessoas de determinado território, a capacidade cognitiva para suportar os dilemas gerados entre a vida espiritual determinada pela lei de Deus e as leis sociais determinadas pela soberania do poder popular. Trata-se de suportar racionalmente a separação entre Fé e Razão, entre Estado e Religião porque, para Lutero, "as leis são propostas para que o comportamento seja regulado segundo certa forma e as questões litigiosas sejam definidas". A lei civil "é necessária e concedida gratuitamente a todo mundo como presente divino na organização política profana, em que se trata de coisas temporais" (LUTERO, 1993, p. 66). No debate contra o humanismo de Erasmo, Lutero defende o "servo arbítrio" de forma dialética porque:

...o ser humano está distribuído em dois reinos: um em que é conduzido por seu
próprio arbítrio e conselho, sem preceitos e mandamentos de Deus, a saber, nas
coisas que são inferiores a ele. [...] Deus [...] lhe concedeu o livre uso das coisas
conforme seu próprio arbítrio [...]. No outro reino, porém, ele não é deixado na
mão de seu próprio conselho, mas é conduzido e guiado pelo conselho de Deus
(LUTERO, 1993, p. 85).

Essa mesma dialética aparece na talvez mais conhecida proposta luterana de que a educação do povo seja promovida pelo Estado, quando dirige aos prefeitos e Câmaras municipais da Alemanha, o apelo de que "se alguém der um ducado para a guerra contra os turcos (ainda que nos assediassem), seria justo que se doassem cem ducados, embora com eles se pudesse educar apenas um garoto de modo a tornar-se um varão verdadeiramente cristão" (LUTERO, 1995, p. 305). Kant trabalhará também de forma dialética contrapondo a liberdade limitada no exercício da função pública e a liberdade ilimitada no uso público da razão. Essa é a definição dialética clássica de exercício da cidadania no contexto das liberdades democráticas. Kant propõe essa definição a partir de uma analogia com a eclesiologia luterana:

\footnotetext{
O uso, portanto, que um pastor em função faz de sua razão diante de sua paróquia é apenas um uso privado; pois esta é uma assembleia de tipo familiar, qualquer que seja sua dimensão; e, levando isso em conta, ele não é livre enquanto padre e não tem o direito de sê-lo, pois ele executa uma missão alheia à sua pessoa. Em contrapartida, enquanto erudito que, por meio de seus escritos, fala ao verdadeiro público, isto é, ao mundo, por conseguinte no uso público de sua razão, o padre desfruta de uma liberdade ilimitada de servir-se de sua própria razão e de falar em seu próprio nome. Pois, querer que os tutores do povo (nas coisas eclesiásticas) voltem a ser menores, é um absurdo que contribui para a perpetuação dos absurdos (KANT, 1783, p. 4-5).
} 
O fundamento epistemológico da pedagogia luterana é a práxis, as possibilidades do mundo. O critério de validade do conhecimento humano é o vínculo ao mundo do trabalho, ao ato humano de transformar a natureza. Lutero era frade da Ordem dos Eremitas Agostinianos de Observância Estrita. Em abril de 1518, poucos meses depois de divulgar as famosas 95 Teses sobre as Indulgências, apresentou-se ao capítulo de seus confrades em Heidelberg. Nessa ocasião, redige um conjunto de 28 teses teológicas e 12 filosóficas. Elas foram aceitas pelo Capítulo. Na última tese de Heidelberg afirma:

O amor humano evita os pecadores e os maus. Cristo diz: "Não vim chamar os
justos, mas pecadores." (Mt 9.13) E este é o amor da cruz, nascido da cruz, que
não se dirige para onde encontra o bem de que possa usufruir, mas para onde
possa proporcionar o bem ao mau e ao pobre (LUTERO, 1987, p. 53-54).

Essa tese antecipa a teologia da justificação somente pela cruz em relação dialética com a teologia da justificação por boas obras. Lutero chama essa implicação de boas obras "no sentido de que as suas obras (do justo ou justificado) não fazem a sua justiça; antes é a sua justiça que faz as obras" (LUTERO, 1987, p. 52). Dois anos depois do Debate de Heidelberg, Lutero foi condenado. Os príncipes alemães, em razão de seus interesses econômicos, assumem a chefia das igrejas da Reforma e, imediatamente, vão implantando legalmente o mercantilismo nos territórios alemães, exterminando os direitos feudais, provocando a Guerra dos Camponeses esmagada em 1525. A disputa entre católicos e protestantes recrudesce, sendo encerrada com a Paz de Augsburgo, em 1555, estabelecendo a fórmula "cuius rex, eius religio", pela qual a religião do rei, seria a religião do povo. Esse precário acordo político, ainda limitado pelo paradigma da cristandade, perderá eficácia no século 17, quando explode a disputa religiosa na Europa com a Guerra dos Trinta Anos (1618-1648) exigindo acordos mais sólidos entre os Estados e as igrejas até o surgimento da concepção do Estado laico no século XX. A laicidade do Estado democrático de direito preserva a liberdade religiosa de cada pessoa, garantindo-lhe a liberdade individual para livremente exercer ou não sua religião e se filiar ou não a uma igreja, sem qualquer constrangimento.

Para a antropologia de Lutero, o conhecimento do que são as boas obras não determina a capacidade para a sua realização. Há, portanto, uma relação dialética que exige a distinção entre epistemologia e ética. Assim a pessoa, exatamente por não possuir o livre-arbítrio, precisa alfabetizar-se e se tornar capaz de realizar uma leitura crítica, capaz de associar fé e práxis, ação refletida e reflexão sobre a ação, pois:

...a Bíblia deve ser lida e interpretada a partir da doutrina do livre exame. É o princípio, seguido pelos reformadores, que assegura a cada leitor do texto bíblico a autoridade e a liberdade interpretativa do referido texto. Com isso, a salvação espiritual não é mais responsabilidade da instituição igreja, mas da condição pessoal do indivíduo diante de Deus (GOMES, 2010, p. 14).

A condição básica para qualquer leitura crítica é a escolarização universal. Suportar a contradição produzida pela liberdade determinada é uma característica da concepção 
pedagógica luterana. Rohden, desde a perspectiva filosófica, assume essa contradição: "O homem é livre de determinações estranhas, mas não de não se autodeterminar, e esta autodeterminação envolve um universo social, que o indivíduo codetermina e dentro do qual, não contra o qual, ele se determina" (1992, p. 128-129). Fora desse limite estamos sob o domínio da irracionalidade e da barbárie.

Gomes (2010, p. 15) percebe na tese de Romanos 1.17 a "solução do problema humano da culpa". Com a premissa de que o ser humano já nasce com a propensão natural do erro e por consequência da culpa, a tentativa é de compensar essas falhas diante de Deus e da sociedade por meio de atos meritórios. Isso é impossível, para Lutero, uma vez "desde seu nascimento, a dívida do homem para com Deus só tende a aumentar. O homem jamais conseguirá por si mesmo saldá-la" (GOMES, 2010, p. 16). Esse é um problema antropológico de natureza jurídica - a culpa - que foi solucionado pela cruz de Jesus Cristo. Lutero exalta a centralidade absoluta da justificação pela fé como sendo vital para a vida da igreja e, na verdade, por uma inferência lógica, para a vida de toda a sociedade: "Se este artigo permanece puro na arena, também a cristandade continua pura, belamente concorde e sem quaisquer seitas. Todavia, se não permanece puro, é impossível resistir a qualquer erro ou espírito fanático" (FÓRMULA DE CONCÓRDIA, 1993, p. 580).

Outra contribuição para o debate atual da pedagogia brasileira também pode ser inferida de uma leitura atenta do livro Da Vontade Cativa. A concepção antropológica dialética de Lutero tem uma surpreendente semelhança com as críticas pedagógicas que apontam para a contradição entre o caráter obrigatório da Educação Básica e as leis do livre mercado na educação, as questões da globalização e suas ingerências financeiras na educação nacional. Assim como com a tese do "livre-arbítrio", a tese do "livre-mercado" desconsidera a dialética da simultaneidade da justiça e do pecado nas pessoas, nas estruturas sociais e nas culturas. De fato, os defensores radicais do "livre-mercado" tendem a ignorar que a liberdade absoluta do mercado produz, ao mesmo tempo, justiça e injustiça. Imaginar que o mercado possa regular-se a si mesmo é ignorar a realidade do pecado de todas as pessoas e das estruturas sociais e culturais que elas criam, mas não controlam com facilidade. $\mathrm{O}$ mercado só pode ser controlado pela razão democrática, isto é, pelo Estado democrático de direito. De modo semelhante, a nova pessoa não pode controlar a si mesma, mas se submete ao controle do governo formado por seus iguais. É a estrutura antropológica da vida democrática pela qual as pessoas tornam-se novas, porque conseguem viver da forma mais razoável possível diante da dura contradição de serem boas e más ao mesmo tempo, na fórmula teológica luterana clássica: "Simul justus et peccator".

Um contraponto paradoxal à antropologia pessimista de Lutero aparece nos Catecismos, cujo texto revela a esperança de Lutero na possibilidade de crianças e leigos aprenderem a traduzir, de forma prática e eficiente, a doutrina cristã para as suas diferentes vivências diárias, vivendo a vontade de Deus na sua realidade em uma experiência cotidiana emancipatória. Exercer uma profissão passa a significar, para o cristão justificado pela fé, o exercício de sua vocação divina. O sacerdócio de todos os crentes pelo batismo justifica a eclesiologia luterana e também a vida produtiva na sociedade. De fato, parece paradoxal o 
modo como a antropologia da vontade cativa se transforma, pelo pensamento catequético luterano, em possibilidade concreta de todas as crianças e pessoas vivenciarem no dia a dia da vida comum a realidade salvífica da doutrina cristã. Essa possibilidade catequética se opera por intermédio de uma intervenção pedagógica orientada e planejada pelos textos dos Catecismos Menor e Maior. Os Catecismos também produzem um sentimento paradoxal em relação à concepção eclesiológica católica vigente nas primeiras décadas do século XVI na Alemanha que, posteriormente, na Contrarreforma católica será profundamente alterada pelo Concílio de Trento (1545-1563). Os Catecismos partem do pressuposto de que pessoas comuns podem aprender a doutrina cristã e, assim, serem capacitadas pela catequese para vivenciá-la de modo prático, mesmo permanecendo na condição de justas e pecadoras. Se todas as pessoas podem, sob determinadas condições de ensino e aprendizagem, viver de acordo com a vontade de Deus, então, a vida dedicada à realização da vontade divina, a única e verdadeira livre vontade, é possível além dos muros dos conventos e monastérios. A vida monástica e a classe sacerdotal perdem sentido como modo privilegiado ou exclusivo de servir piedosamente a Deus. A vida comum do povo pode ser transformada pela educação catequética e, assim, a vida consagrada e santificada pode ser vivida em qualquer lugar e em qualquer profissão. Deus é experimentado nas lavouras, campos e oficinas ou em qualquer lugar onde a gente cristã comum trabalha para ganhar o seu sustento. Paradoxalmente, a antropologia e a eclesiologia derivadas da vontade cativa, transformam o mundo em santuário no qual é possível viver cristandade.

\section{Os CATECISMOS DE LUTERo COMO INSTRUMENTOS DIDÁTICOS DA EDUCAÇÃO IN- TEGRAL DO INDIVÍDUO}

Há 500 anos, a Reforma Protestante Luterana teve o seu processo embrionário intensificado pelo debate de teólogos, acadêmicos e líderes da igreja, convocados por Lutero ao divulgar as 95 Teses conforme prerrogativa dos docentes universitários. Lutero era professor da Universidade de Wittenberg e tinha autorização para convocar debates. Ao longo do tempo, ficou evidente que o movimento necessitava de ajustes e consolidações em várias áreas da igreja. Uma delas foi a catequética. Lutero estava convencido de que a expansão e o sucesso da Reforma dependiam de um sólido fundamento na área educacional (ROSIN, 2009, p. 121). O caminho encontrado para solucionar essa deficiência foi a elaboração e a publicação do Catecismo Menor e Maior, prontos em 1529. "Assim como fica difícil imaginar a Reforma Anglicana sem o Livro de Oração Comum, ou a Reforma Calvinista sem as Institutas da Religião Cristã, assim é impossível conceber a Reforma Luterana sem o Catecismo Menor" (ARAND, 2000, p. 15).

O contexto do qual emergiu a elaboração dos catecismos inclui pelo menos três focos. O pedido particular de um pastor, conflitos teológicos e visitações a igrejas. Todos têm a sua importância, mas o que mais impactou foi a visitação de líderes luteranos, inclusive Lutero, a algumas congregações luteranas na Alemanha, e que demonstrou a fragilidade espiritual dessas comunidades, e cujas decorrências eram percebidas na área social e reli- 
giosa. No campo social, problemas com questões morais que afetavam pessoas individualmente e famílias, e no campo religioso, o descaso com compromissos eclesiais (ARAND, 2000, p. 70-75). O diagnóstico dessa situação foi acoplado a lacunas no ensino e a solução encontrada foi a produção de dois catecismos, o Menor e o Maior. "Meu Deus, quanta miséria não vi! O homem comum simplesmente não sabe nada da doutrina cristã [...] vivendo como os brutos e irracionais suínos" (LUTERO, 1993a, p. 363). Foi essa conjuntura que impulsionou o Reformador a preparar os dois catecismos.

O termo catecismo é atrelado muitas vezes a um exercício de doutrinação, ancorado em perguntas e respostas, que uma vez memorizadas, servem como rito de passagem para um novo status dentro da igreja. Essa é uma compreensão muito estreita dos seus objetivos e do seu papel para com o ser humano. Para Lutero, o conteúdo do Catecismo constitui-se de elementos que definem a identidade cristã em sua jornada na vida, desde o nascimento até a morte. Foi isso que ele quis dizer ao escrever à sua esposa: "Você, querida Katie, leia João e o Catecismo Menor, sobre o qual você certa vez disse: tudo o que está escrito nesse livro é sobre mim" (LUTERO, 1975, p. 308). O que parece claro é que na intenção original de Lutero vinha embutida a ideia de ensinar as pessoas a viver bem essa vida, cada um dentro do seu ofício ou vocação.

Isto na verdade vai ao encontro de outras pesquisas sobre educação feitas em Lutero. De acordo com Gomes (2010, p. 8), por exemplo, o pensamento protestante sobre educação não se restringe tão-somente à possibilidade de desenvolvimento cultural, científico e tecnológico, mas o fundamento está em sua cosmovisão da vida a ser vivida, bem como valores, ideologias e normas, reflexos possíveis perceptíveis na ética e na moral das pessoas. Nesse sentido, um catecismo é um manual para a vida em todas as suas dimensões, espiritual e social. Ou, em outras palavras, a centralidade discursiva do catecismo é a confiança em Deus de quem procede todo bem, não obstante a pecaminosidade humana. Isso torna o seu conteúdo relevante para a existência das pessoas (ARTUSO; KLEIN, 2017, p. 236).

Em geral, desde os primeiros séculos e para os primeiros pais da igreja, o Credo Apostólico e a oração do Pai Nosso, serviram como alicerce para a instrução pré-batismal dos catecúmenos. O Credo providenciava uma espécie de compêndio de toda a Escritura e o Pai Nosso uma companhia apropriada na jornada da vida. Em resumo, o Credo Apostólico era a base fundamental sobre o qual se construía todo o ensino, por ser um sumário dos ensinos centrais da Escritura Sagrada e a oração do Pai Nosso, por ser considerada a melhor das orações, uma vez que foi ensinada pelo próprio Cristo. Esse era, em tese, o fundamento constituinte do ensino cristão (ARAND, 2000, p. 30-31).

Por volta do século XII, o foco continuava sendo o Credo e o Pai Nosso, mas houve uma mudança na dinâmica de transmissão desse conteúdo. A responsabilidade catequética pressupunha o envolvimento dos padrinhos, tanto na obtenção do conhecimento, bem como no ensino e avaliação das crianças. Essa nova situação, considerada como sendo um declínio no sistema catequético, "coincidiu com o declínio do sistema clássico da educação, o que por sua vez tornou o ensino catequético ainda mais complicado" (ARAND, 2000, p. 32). Se essa avaliação for correta, é possível inferir que existiu e pode haver uma 
conexão significativa entre a educação cristã e o sistema de ensino comum, podendo ser feitos intercâmbios de informações e experiências.

Na Idade Média, o Credo e o Pai Nosso continuaram a ter papel decisivo na definição da identidade cristã. $\mathrm{O}$ foco da catequese concentrava-se nesses dois artigos e o seu ensino funcionava como um manual para a vida dentro e fora da igreja. Ao revitalizar o ensino catequético na igreja do seu tempo, Lutero não usou de radicalismos para investir na área catequética da igreja. Ele manteve os dois elementos considerados fundamentais na igreja desde os séculos III e IV, mas, ao mesmo tempo, introduziu uma inovação didático-pedagógica, no sentido de fornecer mais do que um significado histórico, visando a promover uma fé existencial a ser vivida no dia a dia das pessoas, na família, escola e trabalho.

Uma das inserções de Lutero nos catecismos foi o Decálogo, também denominado, quem sabe até de forma equivocada, de "mandamentos", por se tratar essencial e realmente de "dez palavras" (Êx 34.28). Dietrich (1977, p. 60) entende que o Decálogo fixa as bases de Deus para a ordem da sua criação. Se não há uma literalidade absoluta em sua aplicação para o nosso tempo, todo o sistema da lei de Deus conserva indicativos de proteção ao pobre, à viúva e ao órfão, bem como ao estrangeiro (Êx 22.21-24; Dt 10.17-19; Lv 19.33-34).

O Decálogo tornou-se um componente catequético importante na preparação dos catecismos de Lutero, uma vez que o ser humano, como justo e pecador, precisava constantemente das dez palavras de Deus, porque elas definem os contornos da vida segundo a criação de Deus (ARAND, 2000, p. 39). Essa ênfase no Decálogo justifica-se à medida que a abordagem feita sobre ele, careceu de um pensamento convergente ao longo dos anos.

Na igreja primitiva, a moralidade era esboçada na doutrina dos dois caminhos, o caminho da vida e o caminho da morte. Posteriormente, houve uma postura ambivalente com as Dez Palavras, em função de divergências entre a igreja e a Sinagoga. Por um lado, a igreja Cristã percebia-se como recipiente de uma nova aliança e cuja conduta ética estava na lei expressa por Jesus no Sermão do Monte (Mateus 5-7). Por outro lado, a igreja também rejeitou a posição de Marcião, que se posicionou de forma contrária a considerar o Antigo Testamento como palavra de Deus. Ao rejeitar a tese de Marcião, a igreja refirmou o Antigo Testamento como parte da revelação de Deus. A solução estava na afirmação de que não houve um cancelamento das leis do Antigo Testamento, mas uma ampliação nos ensinos de Jesus (ARAND, 2000, p. 35).

A igreja da Idade Média não seguiu o pensamento de Agostinho a respeito do Decálogo como texto normativo para a moralidade cristã. $\mathrm{O}$ modelo teológico seguido foi o do papa Gregório, o Grande (604). Para ele, a base dos preceitos éticos cristãos estava no Evangelho e de forma particular no cultivo das sete virtudes. Amor, esperança, fé, prudência, temperança, coragem e justiça.

Na metade do século XII, houve um renascimento no estudo da Bíblia, especialmente na perspectiva de uma leitura literal do texto bíblico, bem como, em livros antes negligenciados, especialmente os livros proféticos e históricos do Antigo Testamento. Isso, por sua vez, fez o Decálogo assumir o seu papel de moldar a vida moral das pessoas. O desdobramento dessa situação fez que, no século XIII, a igreja conferisse um aspecto mandatório 
na instrução do Decálogo, não obstante uma das ênfases tenha sido a prática da confissão privada (ARAND, 2000, p. 36).

Já no século XIV, a difusão do Decálogo restringiu-se a um papel modesto, uma vez que o tema dominante foram os "pecados", por causa dos sete pecados capitais que demandavam um conhecimento popular para facilitar a operacionalidade da confissão. Por isso, a inclusão das Dez Palavras por Lutero nos catecismos pode ser considerada uma inovação didático-pedagógica e teológica original, na medida em que o reformador as visualizava como sendo a melhor descrição da vontade de Deus para a vida cristã. Além disso, como já exposto brevemente, as Dez Palavras foram incorporadas no sentido de serem percebidas como elementos que fornecem contornos à vida humana criada por Deus (ARAND, 2000, p. 39). Em outras palavras, as Dez Palavras tornam-se um paradigma ético a ser seguido na vida diária das pessoas e com isso ficaram valorizados os ofícios e as vocações nos quais os seres humanos estavam investidos. Além disso, do ponto de vista teológico, ao recolocar as Dez Palavras nos catecismos e posicioná-las logo no começo, Lutero pretendeu demonstrar que é impossível e utópica a concepção de que haja santidade nas pessoas, mas que elas necessitam de forma irreversível e contundente da graça de Deus que as torna inocentes. Esse pensamento vai ao encontro de uma das reflexões feitas ao longo deste artigo e que diz respeito à justificação das pessoas diante de Deus, que ocorre unicamente pela fé, como contribuição da Reforma Luterana para a humanização da educação e das variáveis que a circundam.

Os catecismos de Lutero consolidaram-se com os tópicos do Decálogo, Credo Apostólico, Oração do Pai Nosso, Batismo e Santa Ceia. Porém, uma característica dos catecismos em geral, é que, algumas vezes, determinados temas sejam incorporados e outros suprimidos. Não foi diferente com os catecismos de Lutero. Desde a sua primeira impressão, novos materiais foram adicionados segundo as necessidades e situações (ARAND, 2000, p. 41). Entre essas variações, o mais proeminente acréscimo parece ter sido a "Tábua dos Deveres". Nesse caso, o foco está essencialmente sobre a vida e as responsabilidades familiares, sociais e políticas das pessoas. Essa constatação pode ser feita a partir do que já foi exposto. O Credo Apostólico é mais do que uma elaboração histórica e que deveria ser apreendido intelectualmente e o seu conteúdo foi atrelado à fé a ser vivida pelos indivíduos em seus respectivos contextos diários. O mesmo aconteceu com o Decálogo. Quem "reina" não são mais os pecados, como tinha sido a ênfase na confissão particular e sua conexão com a familiarização com os sete pecados capitais, mas as Dez Palavras, que passaram a ser vistas como dando contornos à vida criada por Deus e a inabilidade do ser humano em obter algum mérito diante de Deus.

Objetivo idêntico ocorre com a "Tábua dos Deveres". No centro da discussão está a vida diária em todas as suas dimensões. A gênese na elaboração de um mapa de deveres das pessoas começou a germinar no "Pequeno Livro de Oração" de 1522. Nele, Lutero esboça algumas instruções para a vida cristã em três situações. Aos clérigos, às pessoas, em geral, em suas diferentes situações na vida e, por fim, uma orientação quanto à honra devida às autoridades governamentais (ARAND, 2000, p. 45). 
Ao produzir os catecismos, Lutero teve em mente a pessoa em sua situação existencial concreta. O pressuposto básico com esse instrumento de ensino está na palavra de Deus. É ela auxílio poderoso contra as forças do mal, é capaz de "afugentar o diabo e maus pensamentos" (LUTERO, 1993a, p. 389). Lutero vai mais longe e afirma que o estudo do Decálogo, conforme revelado nas Escrituras, tem alcance multidimensional na vida das pessoas.

...quem entende os Dez Mandamentos bem e inteiramente, deve entender a Escritura toda, de sorte que pode aconselhar, ajudar, confortar, julgar e decidir em todas as coisas e casos, tanto no plano espiritual quanto no temporal, e pode se juiz sobre doutrinas, ordens, espíritos, direito e o que mais haja no mundo (LUTERO, 1993a, p. 390).

Essa evidência na palavra de Deus, e os frutos que ceifam aqueles que nela meditam, é enfatizada em pesquisas feitas sobre o tópico. Artuso e Klein, por exemplo, dão destaque ao ensino do Catecismo como sendo uma síntese de toda a Escritura Sagrada. "Os catecismos de Lutero representam a evolução e o resultado de diversas catequeses do reformador centradas essencialmente na Escritura" (2017, p. 209). Lutero conclama as pessoas de todos os segmentos sociais e eclesiológicos a viver. Deus concedeu aos seres humanos o privilégio de exercerem o domínio sobre a sua criação, e no ato da criação contínua, sendo máscaras de Deus (ARAND, KOLB, 2008, p. 55). “As criaturas são apenas a mão, o canal e o meio através de que Deus tudo concede, assim como dá seios e leite à mãe para dá-los à criança, e dá grãos e toda espécie de frutos da terra para alimentação" (LUTERO, 1993a, p. 398). As pessoas estão investidas no ofício de serem administradoras e executoras dos planos de Deus, por meio de vocações legítimas, resumidas na Tábua dos Deveres do Catecismo Menor.

O escopo dessa ação humana, assim como retratado no Catecismo Menor, vai desde a dimensão eclesial, autoridade política, passando pela família, até o trabalho e pessoas em geral (LUTERO, 1993a, p. 381-384). As pessoas são, do ponto de vista do Reformador, "santas ordens e estados" (p. 381), nelas cada um deve viver e servir a Deus (ARAND, 2000, p. 46) e para o exercício delas é preciso haver admoestação e instruções. Seu interesse era teológico, mas nas raízes estavam preocupações práticas relacionadas às pessoas (ROSIN, 2009, p. 121).

No Prefácio do Catecismo Menor, Lutero expõe sua concepção teológica e pedagógica. Sua intenção é conduzir uma pessoa à maturidade na fé, de forma que ela possa perceber sua existência à luz da palavra de Deus. Diante da lamentável condição de líderes e do povo em geral, que não sabia nada da vida de acordo com a perspectiva de Deus, Lutero se atém a três princípios básicos fundamentais. No primeiro estágio de aprendizado, é preciso aprender a reter o básico do texto em si (LUTERO, 1993a, p. 364). Uma interpretação dada a esse primeiro momento do ensino é de que Lutero volta ao tempo da cultura predominantemente oral, antes do surgimento da imprensa. A insistência de Lutero, nesse sentido, é de que seja adotada uma uniformidade textual, visando facilitar a memorização do texto (ARAND, 2000, p. 97-98). Embora isso não tenha respaldo na prática pedagógica atual, o objetivo era evitar a confusão na mente dos estudantes. Para tanto, Lutero entende que não 
deveria haver sobrecarga no aprendizado, a fim de que os alunos fiquem "abarrotados" e acabem não memorizando o essencial (LUTERO, 1993a, p. 365). A ênfase de Lutero na memorização também precisa ser vista à luz de seu contexto particular, marcado por um índice considerado de iletrados, mas também, pela consideração à aprendizagem na fixação mental, assim como acontece, por exemplo, com o aprendizado do alfabeto, que uma vez aprendido torna-se impossível esquecer. Porém, vale notar que esse "arquivamento" de informações não tem um fim em si mesmo, mas o anseio de Lutero é que a palavra de Deus torne-se constante companhia na vida concreta das pessoas, a fim de que ela possa moldar novas atitudes, pensamentos e ações (ARAND, 2000, p. 99-100), na medida, também, em que este é apenas o estágio inicial do aprendizado. ${ }^{3}$

A perspicácia pedagógica de Lutero é percebida no segundo estágio do processo de aprendizagem por ele proposto. O segundo passo no processo de aprendizagem ocorre quando se alcança o significado e a compreensão do texto que foi armazenado. Além disso, o procedimento didático deve ser norteado pela paciência e exaustão (LUTERO, 1993a, p. 365; ARAND, 2000, p. 100). Isso pode corresponder ao conceito de cognoscibilidade de Platão, que entende que o verdadeiro conhecimento está além da mera opinião, mas da razão de ser do que é apreendido (PLATÃO, 2014, p. 190-197). O terceiro estágio abrange uma amplitude maior e mais profunda do conhecimento. Nesse caso, ocorre a aplicabilidade do conhecimento obtido e existe uma prática diária, assim como o músico pratica suas escalas musicais, o jogador de futebol treina exaustivamente para fazer o seu melhor numa partida, do mesmo modo o cristão pratica o ensino do Catecismo em seu dia a dia. Igualmente, na perspectiva de Lutero, o conteúdo dos catecismos não precisa nem deve ser limitado a um manual religioso utilizado para definir o status de uma pessoa dentro da igreja, mas serve como guia para as pessoas realizarem a vontade de Deus nos seus ofícios e vocações cotidianas.

\section{Considerações Finais}

\section{Nova Perspectiva Para anAlisar a CONTRIbuição de Lutero à Pedagogia BRASILEIRA}

Como vimos, a comunidade luterana de Leisnig conquistou parcela importante do poder municipal: a ponte, a igreja, o hospital e a escola. O Estatuto estabeleceu mecanismos de autogestão sobre esses equipamentos urbanos, também definiu o processo de eleição do pastor e o controle comunitário sobre a sua pregação. Definiu as formas de colaboração da

\footnotetext{
A questão da memória é assunto controverso. Por um lado, sem memória não há aprendizagem. Ela é a base de todo o saber, pois o cérebro humano funciona através dela. Todo o funcionamento da vida do ser humano está vinculado ao bom funcionamento da memória. "A memória é uma das funções mais importantes do cérebro, está ligada ao aprendizado e à capacidade de repetir acertos e evitar erros" (RELVAS, 2009, p. 56). Por outro lado, estudos apontam que estudantes sul-coreanos precisam memorizar cerca de 60 a 100 páginas a cada semestre. Esse método supostamente está impedindo a criatividade e a capacidade de os estudantes abordarem situações inesperadas (THE ECONOMIST, 2014, p. 7).
} 
comunidade com o governo civil, especialmente, na organização do controle dos estoques de cereais e, portanto, do processo inflacionário. Leisnig experimentou um verdadeiro pacto social. Como se depreende da leitura do Estatuto escrito pelos moradores e publicado por Lutero, os leigos de Leisnig criaram uma espécie de Banco de Fomento, uma escola pública, gratuita, universal, com uma turma para meninos e outra para meninas. Lutero não apenas aprovou o Estatuto, mas o tornou público e o recomendou como modelo para a nova igreja que estava surgindo. Essa prematura experiência de organização eclesial independente no contexto da cristandade parece ter percebido alguns aspectos da futura democracia representativa como o fortalecimento da sociedade civil por meio de mecanismos sociais de autogestão e de controle direto da cidadania sobre parcelas dos aparelhos de Estado, ensejando experiências de redução ou submissão do poder estatal ao poder público.

O longo processo histórico de separação entre política e religião, iniciado na Reforma, permitirá o desenvolvimento, nos séculos seguintes, de uma das características centrais do direito republicano à educação universal, nesse caso, a laicidade da educação pública mediante a garantia pelo Estado de plena liberdade para a educação confessional. Em 1948, a ONU formulou esse direito de modo, praticamente, definitivo. Infelizmente, a versão oficial do governo brasileiro realizada sob a presidência de Getúlio Vargas, traduziu o termo inglês "education" e francês "éducation" das duas línguas oficiais da Declaração Universal dos Direitos Humanos da ONU pelo termo português, instrução. A instrução é parte da educação, mas se limita ao ensino instrumental para treinar o educando para uma atividade laboral. O conceito educação é mais amplo por incluir a formação intelectual, o desenvolvimento moral, a capacitação cognitiva, a criatividade, a estética, a capacidade para o trabalho etc.

\footnotetext{
Artigo XXVI

1. Todo ser humano tem direito à instrução. A instrução será gratuita, pelo menos nos graus elementares e fundamentais. A instrução elementar será obrigatória. A instrução técnico-profissional será acessível a todos, bem como a instrução superior, esta baseada no mérito.

2. A instrução será orientada no sentido do pleno desenvolvimento da personalidade humana e do fortalecimento do respeito pelos direitos humanos e pelas liberdades fundamentais. A instrução promoverá a compreensão, a tolerância e a amizade entre todas as nações e grupos raciais ou religiosos, e coadjuvará as atividades das Nações Unidas em prol da manutenção da paz.

3. Os pais têm prioridade de direito na escolha do gênero de instrução que será ministrada a seus filhos.
}

Em conclusão, a polêmica antropológica entre Lutero e Erasmo ajuda na complexa elaboração da justificação do direito universal à educação. A posição antropológica de Erasmo afirma que as pessoas são "livres para decidir entre o bem e o mal cientes de que a conduta moral preza pelas decisões em direção ao bem e nunca o contrário"; enquanto Lutero "afirma que o mal é inato e inerente a nós" (NASCIMENTO, 2006, p. 100). As duas posições são antagônicas, mas permanecem presentes no pensamento pedagógico contem- 
porâneo. Ambas fundamentam, de forma antagônica, a educação universal. Os humanistas defendem que a educação universal é necessária porque a natureza da humanidade é boa sendo, portanto, possível educar todas as pessoas. Os luteranos defendem a educação universal porque a natureza da humanidade é pecaminosa e, por conseguinte, a educação universal torna-se necessária para civilizar as pessoas e tornar possível a vida social. A antropologia otimista de Erasmo é mais simpática aos pedagogos e pedagogas contemporâneos pelo reforço que lhe deu o pensamento de Rousseau na pedagogia moderna. A antropologia pessimista de Lutero, no entanto, será reforçada por outro moderno, Kant, quando o filósofo parte também da mesma imagem de Lutero - a cavalgadura - para concluir ser "difícil para todo homem tomado individualmente livrar-se dessa minoridade que se tornou uma espécie de segunda natureza" (KANT, 1783, p. 2), havendo, assim, necessidade de a educação ou do que Kant chama de movimento do "Esclarecimento" como via de "saída do homem da minoridade da qual ele próprio é culpado" (KANT, 1783, p. 8).

Qualquer uma das duas justificações do direito e necessidade da educação universal implica na necessidade de a Educação ser mantida pela política educacional do poder civil, do Estado. A universalização da educação, portanto, necessita de um Estado máximo - e não mínimo - no financiamento educacional, talvez até de um Estado gigantesco, na oferta e garantia da educação universal, se considerarmos a exagerada proporção proposta por Lutero de 100 por 1 entre orçamento para a educação e o orçamento militar do Estado nacional. Dessa educação depende o acesso universal à Bíblia, portanto, o fracasso da educação universal impede o conhecimento da salvação pela cruz de Cristo revelado pela leitura crítica da Bíblia. Essa foi a saída proposta por Lutero no debate contra Erasmo. Na melhor das hipóteses, a escola democrática promove mais liberdade, mas não sacia a sede por liberdade. "Que o justo viverá por fé" (Rm 1.17) é a única defesa eficiente contra o livre-arbítrio.

Concluímos que é instigante reler pedagogicamente a tese da "justificação, só pela fé" no contexto garantista da educação universal mantida pelo Estado democrático de direito porque, neste século XXI, vivemos uma cultura de relativismo absolutista que parece justificar tudo e qualquer coisa. Essa releitura talvez ajude o pensamento pedagógico brasileiro na superação de algumas de suas dificuldades com a defesa republicana radical da educação universal. A responsabilidade do Estado é evidente e está bem formulada pela maioria dos pesquisadores em educação. É necessário, no entanto, reconhecer que o Estado assume tal responsabilidade por intermédio do seu corpo docente e dos gestores do sistema de ensino. A responsabilidade pelo alto índice de reprovação e de evasão na escola é do Estado, dos docentes e gestores, mas parece haver uma aceitação passiva ou mesmo conivência dos educadores quanto à reprovação, inclusive, tida como medida pedagógica necessária para garantir o aprendizado, como evidencia ampla pesquisa de opinião realizada pela UNES$\mathrm{CO}$ com professores brasileiros. A maioria atribui "a fatores externos à escola o indicativo principal do sucesso da aprendizagem", levando o profissional da educação a, "de certa forma, se eximir da responsabilidade sobre a aprendizagem dos alunos" (UNESCO, 2004, p. 120). Parece haver um esforço dos docentes para se livrarem da culpa pelo fracasso educacional de seus alunos:

Na percepção dos professores, fica claro que os fatores interpessoais, como o

258Comunicações | Piracicaba | v. 25 | |n. 2 | p. 241-262 |maio-ago. 2018 
acompanhamento da família e a relação com os alunos, exercem mais influência no processo de aprendizagem do que fatores técnicos, tais como a competência do docente, a forma de gerenciamento da escola ou a sua infraestrutura física (UNESCO, 2004, p. 121).

A superação da culpa e a consequente responsabilização racional decorrentes da teologia luterana, poderia oferecer aos docentes da Educação Básica contemporânea uma espécie de "inédito-viável" como definiu Paulo Freire. O professor precisa ter fé nos seus alunos para se transcenderem no seu aprendizado, precisa crer na capacidade de o aluno aprender, no sentido da antropologia otimista de Erasmo. A teologia pode ajudar a pedagogia na compreensão racional da transcendência necessária ao ato de educar no sentido de que tal ato supera a contradição entre o inédito e o viável. A crença do professor no aluno é racional e, ao mesmo tempo, emocional, portanto, não gera culpa, mas responsabilização objetiva. A expressão luterana para esse inédito-viável seria a "cognição do coração" (LUTERO, 1993, p. 25-26). A epistemologia luterana para uma justificação pedagógica da educação universal poderia ser fundamentada na proposta catequética de Lutero, segundo a qual, a capacidade de leitura crítica e o conhecimento decorrente de tal leitura, torna possível para qualquer pessoa, nas suas atividades laborais, vivenciar a salvação universal propiciada pela cruz. Tendo conhecimento de que é justificado pela cruz de Cristo, a pessoa humana torna-se livre para construir sua vida, sua família, sua comunidade, seu país a partir da reflexão objetiva sobre a sua realidade. Justificado pela fé, o catecúmeno adquire a razão limitada, por certo, mas suficiente para construir sua capacidade de compreender e agir na vida social e política conforme a vontade de Deus. Essa capacitação para a vida decorrente do estudo dos Catecismos, assemelha-se à epistemologia construtivista da ciência pedagógica, cuja

...raiz da racionalidade moderna no berço da secularização, queria enfatizar um aspecto às vezes subestimado do projeto racionalista, i. é, a sobrecarga da razão humana com expectativas de origem teológica. [...] ao preencher o espaço aberto pela perda da credibilidade da ordem teológico-feudal, a razão humana ficou exposta a exigências antes atribuídas à ideia de Deus como, p. ex., à qualidade de omnipotente ou omnisciente (FLICKINGER; NEUSER, 1994, p. 30).

Uma das funções da academia é construir respostas cada vez mais razoáveis para os problemas educacionais. Nesse sentido, a eclesiologia, a antropologia e a catequética de Lutero podem trazer contribuições inovadoras para avançar a discussão sobre temas que a pesquisa em educação no Brasil enfrenta. Este artigo fez um exercício hermenêutico de obras teológicas luteranas pouco estudadas pela pedagogia para demonstrar a conveniência de novas pesquisas a respeito da relação transdisciplinar entre a teologia de Lutero e a pedagogia no Brasil. A eclesiologia, a antropologia e a catequética luteranas ajudam na justificação racional do valor transcendental da educação e dos docentes para a democracia que almejamos continuar construindo no país. 


\section{REFERÊNCIAS}

AHLERT, A. Educação, Ética e Cidadania na obra de Martim Lutero: contribuições protestantes para a História da Educação numa aproximação com Paulo Freire. História da Educação, Pelotas, v. 10, p. 81-100, 2006.

. Relações entre a ética social de Lutero e a concepção de Weber sobre a ética protestante no contexto educacional. Orbis, Maracaibo/Venezuela, v. 3, p. 4-22, 2007.

ARAND, C. P. That I May be His Own. Saint Louis: Concordia Publishing House, 2000. ARAND, C. P.; KOLB, R. The Genius of Luther's Theology. Grand Rapids: Baker Academic, 2008.

ARTUSO, V.; KLEIN, C. J. Os Catecismos de Lutero e o uso da Escritura. Horizonte, Belo Horizonte/MG, v. 15, n. 45, p. 206-238, jan./mar. 2017.

BAHMANN, M. K. Lutero Revolucionário. In: LUTERO, M. Obras de Martin Lutero. Tomo VII. Buenos Aires: Publicaciones El Escudo, 1977, p. 85-95.

BARBOSA L. M. R. Estado e educação em Martinho Lutero: a origem do direito à educação. Cadernos de Pesquisa, São Paulo, v. 41, p. 866-885, 2011.

. As concepções educacionais de Martinho Lutero. Educação e Pesquisa, São Paulo, v. 33, p. 164-184, 2007.

CARDOSO, C. F. S. O Egito antigo, 8. ed. São Paulo: Brasiliense, 1984.

DIETRICH, S. de. O Desígnio de Deus. São Paulo: Loyola, 1977.

FLICKINGER, H.-G.; NEUSER, W. Teoria de auto-organização: as raízes da interpretação construtivista do conhecimento. Porto Alegre: Editora da PUC/RS, 1994.

FÓRMULA DE CONCÓRDIA. In: Livro de Concórdia, 4. ed. São Leopoldo/Porto Alegre: Sinodal/Concórdia, 1993.

GOMES, A. M. de A. Ética cristã, Educação e Responsabilidade social em Martinho Lutero. Ciências da Religião - História e Sociedade. São Paulo, v. 8, n. 2, p. 5-24, 2010.

JARDILINO, J. R. L. Lutero \& a educação. Belo Horizonte: Autêntica, 2009.

KANT, I. Resposta à pergunta: O que é o Esclarecimento? (5 de dezembro de 1783). [Traduzido por Luiz Paulo Rouanet.] Disponível em: http://www.uesb.br/eventos/emkant/ texto_II.pdf, acesso em 21.04.2017.

KEIM, E. J. A educação e a revolução social de Martinho Lutero. EccoS, São Paulo, v. 12, n. 1, p. 219-237, jan./jun. 2010.

LINDBERG, C. As reformas na Europa. São Leopoldo: Sinodal, 2001. 
LUTERO, M. Aos conselhos de todas as cidades da Alemanha para que criem e mantenham escolas cristãs. In: Martinho Lutero: Obras selecionadas. Ética: Fundamentos - Oração - Sexualidade - Educação - Economia, v. 5. São Leopoldo; Porto Alegre: Sinodal; Concórdia, 1995, p. 302-325.

. Catecismo Menor e Maior. In: Livro de Concórdia, 4. ed. São Leopoldo/Porto Alegre: Sinodal/Concórdia, 1993a.

. Estatuto para uma Caixa Comunitária. Orientação sobre como lidar com o patrimônio eclesiástico. In: . Martinho Lutero: Obras selecionadas. Vida em comunidade: Comunidade - Ministério - Culto - Sacramentos - Visitação - Catecismos - Hinos, v. 7. São Leopoldo; Porto Alegre: Sinodal; Concórdia, 2000, p. 37-64.

. O Debate de Heidelberg. In: . Martinho Lutero: Obras selecionadas. Os Primórdios. Escritos de 1517 a 1519. São Leopoldo; Porto Alegre: Sinodal; Concórdia, 1987, v. 1. Tese 28.

. Da Vontade Cativa. In: . Martinho Lutero: Obras selecionadas. Debates e Controvérsias, II. V. 4. São Leopoldo; Porto Alegre: Sinodal; Concórdia, 1993, p. 11-216. . Letters III. In.: KRODEL, G. G. (Editor), Luther's Works, v. 50. Philadelphia: Fortress Press, 1975.

MCEVEDY, C. Atlas da História Antiga, 2. ed. São Paulo: Verbo, 1990.

NASCIMENTO, S. F. do. Erasmo e Lutero: o livre arbítrio da vontade humana. Revista de Filosofia: Aurora, Curitiba, v. 18, n. 23, p. 89-103, jul./dez. 2006.

PAULY, E. L. Ética, educação e cidadania: questões de fundamentação teológica e filosófica da ética na educação. São Leopoldo, RS: Sinodal, 2002.

. A laicidade na educação a partir da polêmica teológica entre Erasmo e Lutero. EccoS, São Paulo, n. 26, p. 107-122, jul./dez. 2011.

PLATÃO. A República. Rio de Janeiro: Nova Fronteira Participações, 2014.

RELVAS, M. P. Fundamentos Biológicos da Educação. Rio de Janeiro: WAK Editora, 2009.

ROHDEN, V. Razão prática e direito. In: . (Coord.). Racionalidade e Ação. Porto Alegre: Ed. da Universidade/UFRGS, Instituto Goethe/ICBA, 1992.

ROSIN, R. Luther on Education. In: WENGERT, T. J. (Org.). The Pastoral Luther. Grand Rapids: William B. Eerdmans Publishing Company, 2009.

THE ECONOMIST Intelligence Unit. The Learning Curve 2014. Report. Pearson. Disponível em: <http://thelearningcurve.pearson.com/content/download/bankname/components/filename/The_Learning_Curve_2014-Final_1.pdf>, acesso em 10 de abril de 2017. 
UNESCO. Organização das Nações Unidas para a educação, a ciência e a cultura. O Perfil dos professores brasileiros: o que fazem, o que pensam, o que almejam - Pesquisa Nacional UNESCO. São Paulo: Moderna, 2004.

WEBER, H-R. Jesus e as crianças. São Leopoldo: Sinodal, 1986.

\section{DAdOS DOS AUTORES}

\section{Evaldo Luis Pauly}

Doutor em Educação pela Universidade Federal do Rio Grande do Sul. Docente do Programa de Pós-Graduação em Educação da Universidade La Salle (Canoas). Canoas/RS Brasil.evaldo@unilasalle.edu.br

\section{Anselmo Ernesto GrafF}

Doutorando em Educação em Educação da Universidade La Salle. Docente na Universidade Luterana do Brasil (Canoas) e do Seminário Concórdia (São Leopoldo). Canoas/RS -Brasil. anselmo.graff@ulbra.br

Submetido em: 21-4-2017

Aceito em: 18-12-2017 